\title{
Histopathological diagnosis of surgical specimens in a Tertiary Hospital at Dhaka
}

Prof. Md.Tahminur Rahman1, Sonia Shirin2,

Tanjila Tahmin Sarnali ${ }^{3}$, Mahbuba Ashrafi Mumu 4

\begin{abstract}
To determine the relative frequencies of different diseases in surgically resected specimen sent for histological diagnosis at a tertiary hospital at Dhaka. A total of 399 surgically resected specimens were sent for histopathological diagnosis. Out of these specimen 236(59.1\%) were benign, $115(28.8 \%)$ were inflammatory, $6(1.5 \%)$ was premalignant condition, $37(9.3 \%)$ were malignant lesions and $5(1.3 \%)$ was inadequate for diagnosis.. The mean age $\pm S E$ of the patients was $42.47 \pm .752$ years. The male female ratio was 1:3. Statistical significant difference was found between benign and malignant lesion in relation to age $(p<000)$ and sex $(p<.003)$. The commonest malignancy is squamous cell carcinoma (72.62\%). It reaffirm and emphasizes the need for histological diagnosis of all surgically removed specimen, other wise the patient may suffer from undiagnosed disease and this will lead to increase the suffering of the patient due to lack of treatment and also increased morbidity and mortality.
\end{abstract}

Key words: Surgically resected specimen, histopathological diagnosis and its importance

\section{Introduction}

Diagnosis of disease now a days is very complex and depends on clinical history, physical examination and different diagnostic modalities like radiology and imaging, FNAC, Biopsy, histopathology of the resected sample, cytology, Tumor markers, Immunology \& serology and Genetic studies because of diversifying presentation of disease. However, the most important and confirmatory diagnostic tool for surgically resected specimen is histopathology. So it is man datory to sent all surgically removed specimens for histopathological examination throughout the World as a common practice. The pattern of disease in surgically resected specimens are not same in all countries rather it is diversifying. With this background the present retrospective study was designed to find out the relative frequency of different lesions like inflammatory, benign and malignancy in surgically removed specimen and to correlate with the clinical diagnosis. This will throw some light regarding the type of lesion found in surgically resected specimen by histopathology and this will reflect an over all impression of benign and malignant disease in surgically resected sample in Bangladesh.

\section{Methods}

All the samples received between the period from January 2007 to August 2009 sent to Bangladesh Institute of Health Science (BIHS) Laboratory at
Mirpur, Dhaka were included in this study. These samples were resected and sent by different surgeons like Dermatologist, Gynaeco logist, Endoscopist and General Surgeon for histological diagnosis of surgically resected samples. The samples were processed for routine Haematoxylin and Eosin (H\&E) stain after grossing, section cutting, embedding, clearing and staining. The diagnosis was made light microscopically and the report was sent to the referring physician.

\section{Results and Observations}

The data were analysed statistically using SPSS programme, and student $t$ test and Chi square test were done to find out if there is any statistical significance. The results are shown in table I, II and III.

Table-I

Histopathological diagnosis by sex of subject

Type of diagnosis

\begin{tabular}{lcccccc}
\hline $\begin{array}{l}\text { Sex of } \\
\text { subject }\end{array}$ & $\begin{array}{c}\text { Bengin } \\
n(\%)\end{array}$ & $\begin{array}{c}\text { Pre } \\
\text { Malignant }\end{array}$ & $\begin{array}{c}\text { Malignant } \\
n \%\end{array}$ & $\begin{array}{c}\text { Inflammation } \\
n \%\end{array}$ & $\begin{array}{c}\text { Inadeqate } \\
\text { for diagnosis }\end{array}$ & $\begin{array}{c}\text { Total } \\
n \%\end{array}$ \\
\hline Male & $43(41.7 \%)$ & $1(1 \%)$ & $15(14.6)$ & $41(39.8 \%)$ & $3(2.9 \%)$ & $103(100)$ \\
Female & $193(65.2 \%)$ & $5(1.7 \%)$ & $22(7.4 \%)$ & $74(25 \%)$ & $2(0.7 \%)$ & $296(100)$ \\
Total & $236(59.1 \%)$ & $6(1.5 \%)$ & $37(9.3 \%)$ & $115(28.8 \%)$ & $5(1.3 \%)$ & $399(100)$ \\
Mean (土SE) age was $42.47( \pm .752)$ and M: F was 1:3.
\end{tabular}

1. Prof. Md.Tahminur Rahmam, Professor \& Head, Pathology, Ibrahim Medical College and Consultant Grade 1 BIHS, Mirpur, Dhaka

2. Dr. Sonia Shirin, Lecturer, Community Medicine, Ibrahim Medical College, Shahbagh, Dhaka

3. Dr. Tanjila Tahmin Sarnali, Inservice Trainee, Bangladesh Medical College, Dhanmondi, Dhaka

4. Mahbuba Ashrafi Mumu B.Sc(Honours) in Laboratory Science, BIHS, Mirpur, Dhaka 
Table-II

Demographic variables of histopathological diagnosis $(n=273)$

\begin{tabular}{lccc}
\hline Histopathological & $\begin{array}{c}\text { Number of } \\
(\%)\end{array}$ & $\begin{array}{c}\text { Age difference } \\
\text { t-test }\end{array}$ & $\begin{array}{c}\text { Sex differenc } \\
\text { X2-Test }\end{array}$ \\
\hline Benign & $236(86.4)$ & & \\
Malignant & $37(13.6)$ & .000 & .003 \\
Total & $273(100)$ & & \\
\hline
\end{tabular}

Table-III

Histopathological diagnosis of difference system

\begin{tabular}{|c|c|c|c|c|c|c|c|c|}
\hline \multirow{2}{*}{$\begin{array}{l}\text { Tissue } \\
\text { under } \\
\text { system }\end{array}$} & \multirow[b]{2}{*}{ Benign } & \multirow[b]{2}{*}{ Pre } & \multicolumn{3}{|c|}{ Type of diagnosis } & \multirow[b]{2}{*}{ Total } & \multicolumn{2}{|c|}{$\begin{array}{l}\text { Difference } \\
\text { between be } \\
\text { and malignan }\end{array}$} \\
\hline & & & Malignant & Inflammation I & Inadequat & & Age & $s$ \\
\hline Female & $126(85.1 \%)$ & $2(1.4 \%)$ & $5(3.4 \%)$ & $13(8.8 \%)$ & $2(1.4 \%)$ & $148(100 \%)$ & .004 & \\
\hline \multicolumn{9}{|l|}{ genital } \\
\hline \multicolumn{9}{|l|}{ tract } \\
\hline GIT & $10(25 \%)$ & $1(2.5 \%)$ & $7(17.5 \%)$ & $21(52.5 \%)$ & $1(2.5 \%)$ & $40(100 \%)$ & ns & (n) \\
\hline Skin & $63(76.8 \%)$ & $0(0 \%)$ & $8(9.8 \%)$ & $11(13.5 \%)$ & $0(0 \%)$ & $82(100 \%)$ & .003 & (n) \\
\hline Gallbladl & ilder $3(4.9 \%)$ & $0(0 \%)$ & $0(0 \%)$ & $58(95.1 \%)$ & $0(0 \%)$ & $61(100 \%)$ & & \\
\hline Buccal & $7(35 \%)$ & $3(15 \%)$ & $10(50 \%)$ & $0(.0 \%)$ & $0(0 \%)$ & $20(100 \%)$ & ns & (n) \\
\hline \multicolumn{9}{|l|}{ mucosa } \\
\hline \multicolumn{2}{|c|}{ Appendix $6(33.3 \%)$} & $0(0 \%)$ & $0(0 \%)$ & $10(55.5 \%)$ & $2(11.1 \%)$ & $18(100 \%)$ & & \\
\hline Eye & $0(0 \%)$ & $0(0 \%)$ & $3(100 \%)$ & $0(0 \%)$ & $0(0 \%)$ & $3(100 \%)$ & & \\
\hline ENT & $4(50 \%)$ & $0(0 \%)$ & $3(37.5 \%)$ & $1(12.5 \%)$ & $0(0 \%)$ & $8(100 \%)$ & & \\
\hline Breast & $12(92.3 \%)$ & $0(0 \%)$ & $1(7.7 \%)$ & $0(0 \%)$ & $0(0 \%)$ & $13(100 \%)$ & & \\
\hline Genito & $5(83.3 \%)$ & $0(0 \%)$ & $0(0 \%)$ & $1(16.7 \%)$ & $0(0 \%)$ & $6(100 \%)$ & & \\
\hline \multicolumn{9}{|l|}{ urinary } \\
\hline \multicolumn{9}{|l|}{ system } \\
\hline Total & $236(59.1 \%)$ & $6(1.5 \%)$ & $37(9.3 \%)$ & $115(28.8 \%)$ & $5(1.3 \%)$ & $399(100 \%)$ & & \\
\hline
\end{tabular}

Age difference between benign and malignant of female genital tract and skin were significant

\section{Discussion}

It is evident from the present study that malignant lesion is very common in surgically resected specimen. A total of $37(9.3 \%)$ out of 399 sample came out as malignant. Of this, malignancy is more frequent in tissue from buccal mucosa $50 \%$ and GIT(17.5\%). Premalignant lesion was also common in buccal mucosa $15 \%$, GIT $2.5 \%$ and Female genital tract $1.4 \%$. So any abnormality in buccal mucosa, esopahagus, pyriform fossa, tonsil in the form of leuko oplakia,erythroplakia, non healing ulcer, tumor should be sent for immediate histopathologiocal diagnosis. As we found (50\%) of cases from these sites were malignant implying importance of early diagnosis by histopathology. The age range of buccal mucosal lesion varied from $24-71$ years, the mean age 54.86 years and $M: F$ ratio $1: 2$. The predominant age group for malignant lesion in buccal mucosa were $41-80$ years $85 \%$ and $15 \%$ in $21-40$ years age group. The common age group for pre malignant lesion were also 41-80 years age group $60 \%$ and $40 \%$ in $21-40$ years age group.

Other important finding of this study is that the most common cancer is squamous cell carcinoma $72.26 \%$, most common in oropharynx and esophagus, skin specially nonhealing ulcer, followed by adenocarcinoma and carcinoma in situ(CIS) $7.89 \%$ each, the common site of adenocarcinoma is stomach and CIS is cervix. There is female preponderance $65.78 \%$ vs 34.21 in males and the mean age is 52.86 years. The most commonly affected age groups are $61-80$ years $44.73 \%$, followed by $41-60$ years $36.84 \%$ contributing $81.57 \%$ between $41-80$ years. Also female preponderance in both age range $23.68 \%$ and $26.31 \%$ vs $13.15 \%$ and $18.42 \%$ for males. The $M: F$ ratio is $1: 1.71$. This findings are consistent with the findings of others who found the most common type of malignancy is squamous cell carcinoma followed by adenocarcinoma in surgically resected specimens. In Nigeria the proportion of cervical cancer is less and the mean age of gynaecological cancers was 44.2 years. In our study the mean age for all malignant lesions was 52.86 years a bit higher than Nigeria.This difference may be due to geographical and sociocultural background and late diagnosis in Bangladesh. 5 biopsy $(1.26 \%)$ specimen showed granulomatous inflammation most likdely Tuberculosis, age range of the patient were 24-62 years, male 3 female 2 cases. Nature of specimen include chronic absecess in arm 2, Lymphnode 2, non healing ulcer on skin in Labia 1. So any non healing ulcer, chronic abscess and enlarged lymphnode should be sent for histopathologgical diagnosis to exclude Tuberculosis in Bangladesh. As there is reemergence of tuberculosis it is important to exclude Tuberculosis in developed, developing and poor countries. Although granulomatous inflammation particularly Tuberculosis is common Bangladesh but less number or samples were sent for histopathological diagnosis. This is because of th fact that the Clinicians starts antituberculous treatment depending on clinical and some routine laboratory tests like CBC, ESR, MT, Xray. As such number of granuloatous inflammation was less in this study. Benign lesion is common in Gynecological samples like hysterectomy Specimen $85.1 \%$ vs $3.4 \%$ malignant. The age range of the hysterectomy patient was $28-63$ years and the mean age of the patients was 47.87 years. One thing is very clear that adenomyosis (39\%) and chronic cervicitiis $(55 \%)$, are frequent finding in resected Uterus samples followed by leiomyoma(18\%), polyp in $(7.86 \%)$, ovarian cyst in $(12.35 \%)$ of samples. Most of these women presented with menorrhagia, low back pain and white discharge, dysparunia. Most of the endometrium samples were sent for therapeutic abortion and some for infertility to 
assess the endometrial status. So these were benign. Out of four cervical biopsies received all showed cervical cancer, carcinoma in situ (CIS). This indicates and emphasizes the need for early diagnosis of cervical cancer by cervical screening like Paps smear test. This must be ensured by the Gynaecologists.

Among the breast lesion $92.3 \%$ were benign and $7.7 \%$ were malignant. The age range of these patients were $15-52$ years and the mean age were 31 years, as such most of the breast lesions came out as benign and one malignant case the age was 52 years. This is consistent with findings of others.

Among the total 19 appendix resected $26.31 \%$ were males, $73.65 \%$ were females, age range $14-78$ years and the mean age is 38.94 years, Male female ratio $M: F 1: 2.8$. Out of this were acute and recurrent appendicitis was $55.6 \%$ and benign lesions were composed of obliteration of lumen by faecolith, lymphoid hyperplasia. was present is $33.3 \%$ cases and no case of malignancy was seen.

\section{Conclusion}

This study emphiasizes the need and reaffirm the importance of Clinico-pathological correlation and sending of all surgically resected samples for histopathological diagnosis. Routine screening tests like Paps smear for all women above 35 years should be advised. Also any lesion in buccal mucosa, oropharynx, nasal mass, eye lesions should be sent for histological diagnosis. By doing these we will be able to diagnose malignant lesions early and can define better strategies for its early diagnosis and treatment plan. This will also reduce the increased morbidity and mortality in these patients.

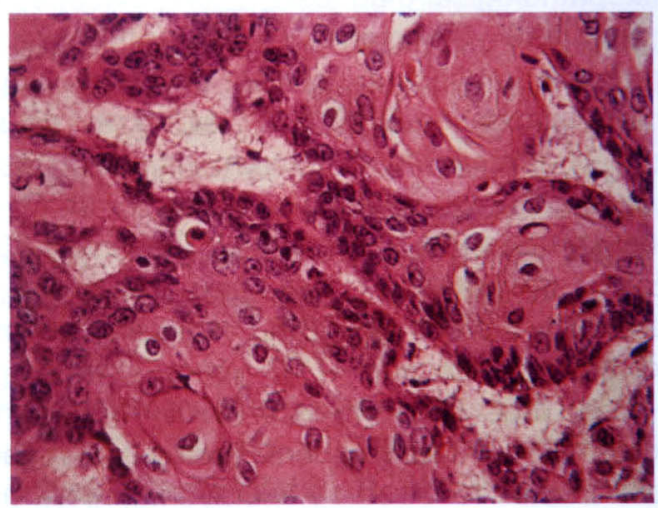

Microphotograph1: Showing a squamous cell carcinoma, H\&EX20 showing well differentiated anaplastic squamous cells and keratin pearl

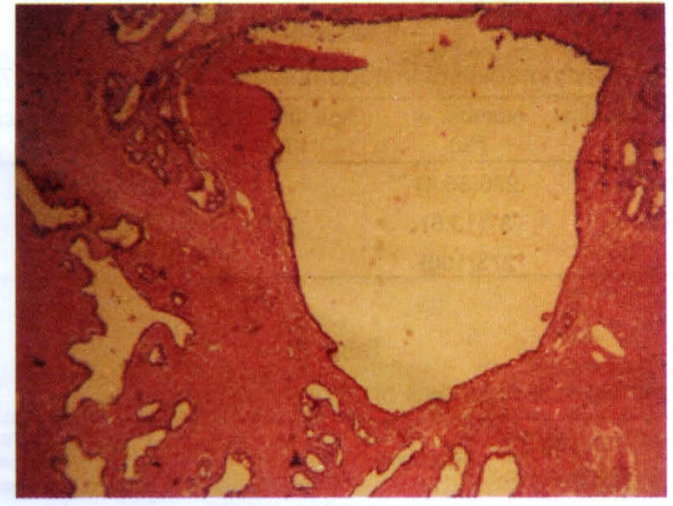

Microphotograph2: Showing foci of adenomyosis, H\&E 20 showing endometrial glands within myometrium

\section{Acknowledgement}

The authors gratefully acknowledge the permission of BIHS authority for allowing to review the records and the consultants for sending the samples for histopathology to BIHS

\section{References}

1. Robbins and Cotran Pathologic Basis of Disease. EditorKumar, Abbas, Fausto. 7th edition, 2004 Publisher Elsevier India Ltd.

2. Talukdar SI, Haque MA, Huq MH etal. Histopathological analysis of hysterectomy specimens. Mymensing Med J.2007;16(1):81-84

3. Talukdar SI,Haque MA,Alam MO et al. Histopathology based cancer pattern in Mymensing region of Bangladesh. Mymensing Med J. 2007;16(2):160-64

4. Talukdar SI, Haque MA, Alam MO et al. Gynecological cancers in surgical specimens in Mymensing, Bangladesh. Bang J Pathol. 2008; 23(1):2-5

5. Kyari $\mathrm{O}$, Nggada $\mathrm{H}$, Malrioga A. Malignant tumours of female genital tract in North Eastern Nigeria J.2000; 77(10):334-8

6. Nkvekyer K.Pattern of gynecological cancers in Ghana. East. Afr Med J 2000; 77(10):334-8

7. Briggs ND,Katchy KC.Patterns of primary gynaecologuical malignancies as seen in the tertiary hospital situated in the rivers state of Nigeria.Int $\mathrm{J}$ gynecol Obstet1990;31(2);157-61

8. You W,Dainty LA,Rose GS etal.Gynecologic malignancies in women aged less than 25 years. Obstetric \& Gynecology 2005;105:1405-09

9. Chhabra S,Sonak M, Prem V etal.Gynecological malignanciues in rural Institute in India. J Obstet Gynecol 2002; 22(4):426-29

10. Badar F, Anwar N, Meerza F etal. Cervical carcinoma in Muslim family. Asian J Cancer Prev.2007;8(1):24- 